\title{
Galanthus elwesii Hook (Amaryllidaceae) in the flora of Kosovo
}

\author{
Zeqir Hashani ${ }^{1}(\mathbb{D})$, Qenan Maxhuni ${ }^{2}$ (D) Rrahman Ferizi $^{3 *}$ (1) \\ Almir Abdurrahmani ${ }^{1}{ }^{10}$, Xhavit Mala ${ }^{4}$
}

Key words: Galanthus elwesii, distribution, Kosovo, Sharri Mts., first record, Vraça.

Ključne besede: Galanthus elwesii, razširjenost, Kosovo, Šar Planina, prva najdba, Vraça.

\begin{abstract}
Flora of the southern part of Kosovo has previously been studied in a limited way due to the difficult terrain and the fact that up to the 1990s it was a military area. In this paper we report Galanthus elwesii Hook for the first time from Kosovo. This species is found in different habitats, mainly in siliceous substrate or wet meadows of the Dragash Municipality, South Kosovo. This species was collected in the Vraça Mountains, near Restelica, (part of National Park 'Sharri') on the road leading to the border with Macedonia. The study area consists of territories belonging to the phytogeographic system Skardon-Pindik (Sharri-Pindi) and includes the mountain ranges of Sharri. This research comprises the presence, description, spread and mapping of the species.

Izvleček

Zaradi težavnega terena in ker je bilo tu do leta 1990 vojaško območje, so floro južnega dela Kosova preučevali le v omejenem obsegu. V članku poročamo o prvi najdbi vrste Galanthus elwesii Hook na Kosovu. Vrsto smo našli na različnih rastiščih, predvsem na silikatni matični podlagi, oziroma na vlažnih traviščih v naselju Dragash (južno Kosovo). Vrsto smo našli na gorovju Vraça pri naselju Restelica, ki je del naciolanega parka Šar, ob cesti, ki vodi proti meji z Makedonijo. Obravnavano območje pripada Skardo-pindski fitogeografski enoti (Šarsko-pindski) in vključuje predele gorovja Šar Planina. V članku predstavljamo opis vrste in njeno razširjenost.
\end{abstract}

Received: 8. 5.2018

Revision received: 8.11 .2018

Accepted: 20. 11. 2018

\footnotetext{
1 UBT - Higher Education Institution, Lagjja Kalabria p. n., 10000 Prishtine, Kosovo.

2 Kosovo Institute for Nature Protection, Rr. L. Haradinaj, ish Rilindja, 10000 Prishtine, Kosovo.

3 University of Pristine, Faculty of Medicine, Rr. Bulevardi i Dëshmorëve, p. n. 10000 Prishtine, Kosovo.

4 Directorate of National Park "Sharri”, Rr. Flamuri p. n. Petrovë, 20000 Prizren, Kosovo.

* Corresponding author. E-mail: rrahman.ferizi@uni-pr.edu
} 


\section{Introduction}

The genus Galanthus L. belongs to the Amaryllidaceae family, which contains more than 1100 species divided into 75 genera (Rexhepi 1986). Species diversity centres are in Greece, Caucasus, Balkans and the Taurus Mountains of southern Turkey (Bishop et al. 2006). The species of genus Galanthus are difficult to distinguish and classify. The taxonomy of this genus is still considered problematic due to the large morphological variability of the species (Davis \& Barnett 1997). Studies of Galanthus in western Turkey, Greece and Serbia have indicated that the majority of populations previously identified as G. elwesii, in fact belong to G. gracilis. Because of the close similarity between these two species, further studies are needed to determine their factual distribution and classification in these countries. The species of this genus are widely used as ornamental and pharmaceutical plants (Berkov et al. 2004).

The Galanthus elwesii description was made for the first time by J. D. Hooker (1875). The species is named after H. J. Elwes (1846-1922) and it was placed under protection in 1990 as an endangered species (CITES). As do many other species of genus Galanthus, G. elwesii grows on limestone substrate and on volcanic and metamorphic bedrock as well, mainly distributed in warm countries with moderate, subtropical and tropical climates (Davis 1999). It grows mainly at elevations between $800 \mathrm{~m}$ and $1.700 \mathrm{~m}$, though most species occur at elevations above $1000 \mathrm{~m}$ (Bishop et al. 2006).

According to Rexhepi (1986), the genus Galanthus is represented in Kosovo only with Galanthus nivalis. Also, Jovanovic (2016) report this species for Serbia, showing the occurrence within the territory of Kosovo on a map, however, unlike all other records in that work, no exact record of G. elwesii is listed from the territory of Kosovo.

\section{Materials and methods}

Plant material was collected and herbarised within several floristic expeditions, conducted in the Sharri Mountains and surrounding areas in the period 2011-2015. During field expeditions, relevant data were recorded related to vegetation type, and the habitat, composition of substrate and the altitude where species were located. For species found along transects, high-resolution digital photos were taken. The largest number of transects conducted were on the north-western and southern sides of the Sharri Mountain ranges (mainly Vraça Mountains) focusing on the road connecting Dragash to Brod, the Dushka canyon and Brod canyon; connecting transect Hotel Arxhena to the Vraça Mountains and Hotel Arxhena to Restelica; Dragash to Restelica; Restelica Shishtavec to Kallabak; Restelica to above Lukova field in the border with Macedonia; Restelica to the Vraça Mountains (alpine pastures and south-western sides). Herbarised plants and the photo gallery are stored in the archives of the first author of this publication and since 19.11.2015, are also deposited in the National Herbarium in Tirana, Albania. In order to determine the plant species, several literature sources were consulted, as well as foreign literature published on the flora, vegetation and geomorphology of the explored territory (Adamović 1911, Stjepanović-Veseličić 1975, Shuka et al. 2011, Tutin et al. 1964, 1980), as well as the flora of neighbouring countries (Strid et al. 1991).

\section{Results and Discussion}

\section{Galanthus elwesii Hook.f., Bot. Mag. 101: t. 61661875. \\ Synonyms: Chianthemum elwesii (Hook.f.) Kuntze \\ Galanthus nivalisL. subsp. elwesii (Hook.f.) Gottl.}

Herbaceous perennial plants with different shapes, with below-ground shoots, usually with bulbs and less frequently with short rhizomes with different shapes, with below-ground shoots, usually with bulbs and less frequently with short rhizomes. G. elwesii grows from a bulb which is usually ovoid or spherical $2.1-2.7(-3.5) \times(1.5)$ $1.8-2.5(-3) \mathrm{cm}$, usually located deep in the cavities in soil or in the rocks, between 15 and $22 \mathrm{~cm}$ under the ground surface, with a short stalk which may be of $3-6 \times$ $0.5-0.8 \mathrm{~cm}$. Above the ground, two or three green leaves develop, which are more or less linear arising from the base of the plant. Leaves are narrowly oblanceolate, usually without petiole, slightly to markedly broader in the middle to upper third, sometimes narrowed at the base, at flowering stage are (4.8 - ) $5.5-25(-28) \times(0.7-) 2$ $-3.4(-3.6) \mathrm{cm}$, and after flowering are $10-26(-32) \times$ $(0.7-) 2.2-3.5(-3.7) \mathrm{cm}$, twisting on the vertical axis (Figure 1). It has white flowers and outer perianth segments composed of sepals and petals. The inner segments of perianth are obovate with green markings sometimes covering up to half of the segment, or each segment with two marks, one apical and one basal (Figure 2). Anthers tapering to a long point, capsule \pm spherical, $10-16 \mathrm{~mm}$ in diameter, seeds pale brown (Davis 1999). Species of genus Galanthus are very similar and hard to distinguish from each other (Jovanović et al. 2012, 2016, Shuka et al. 2011).

According to Davis (2013), G. elwesii is very similar to $G$. gracilis, as both species have glaucous leaves perianth segment (Berkov et al. 2011, Yuzbaşioğlu 2012). 

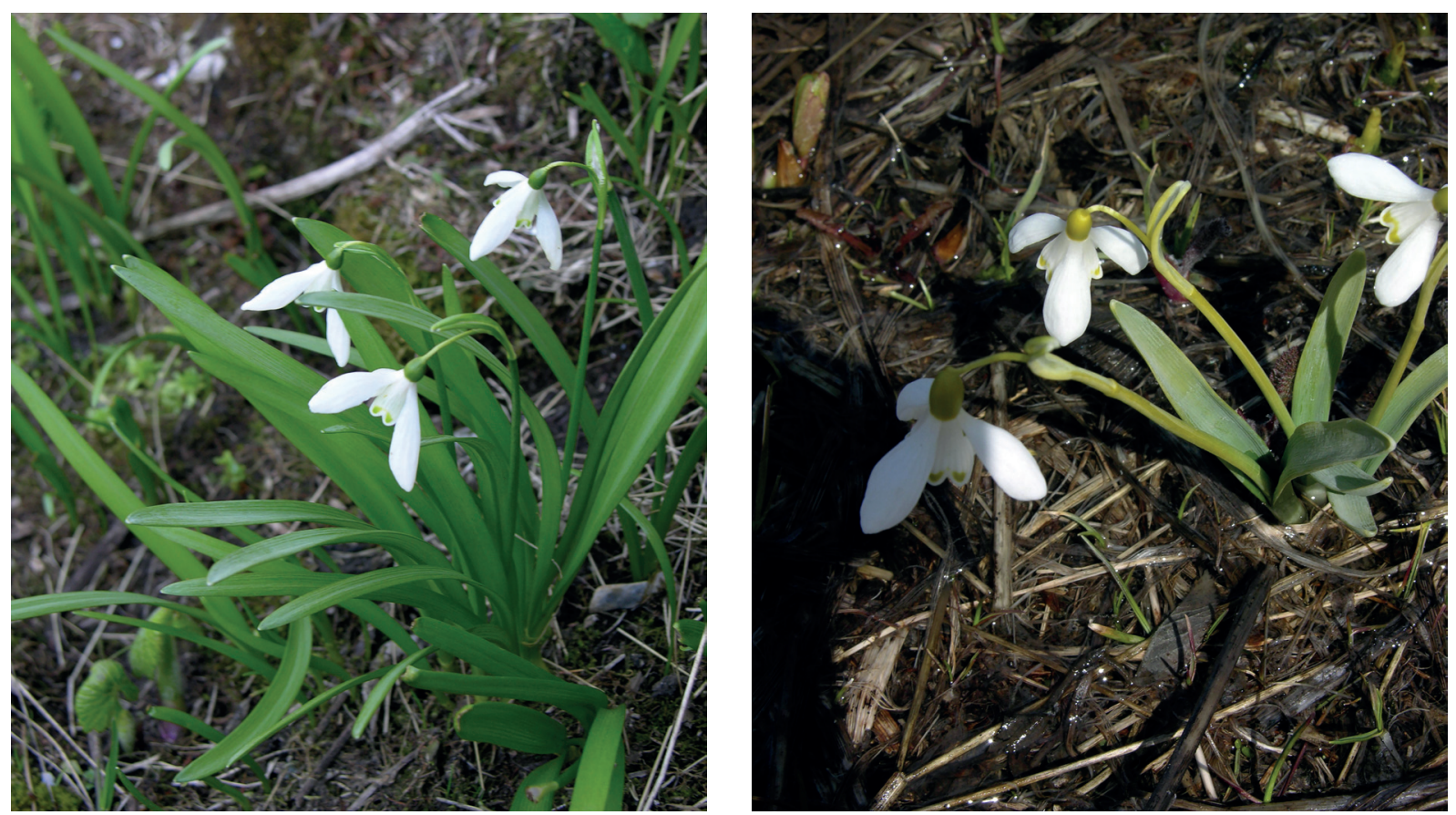

Figure 1 (a \& b): Galanthus elwesii in a flowering phase (photo Z. Hashani). Slika 1 (a \& b): Galanthus elwesii v cvetu (foto Z. Hashani).
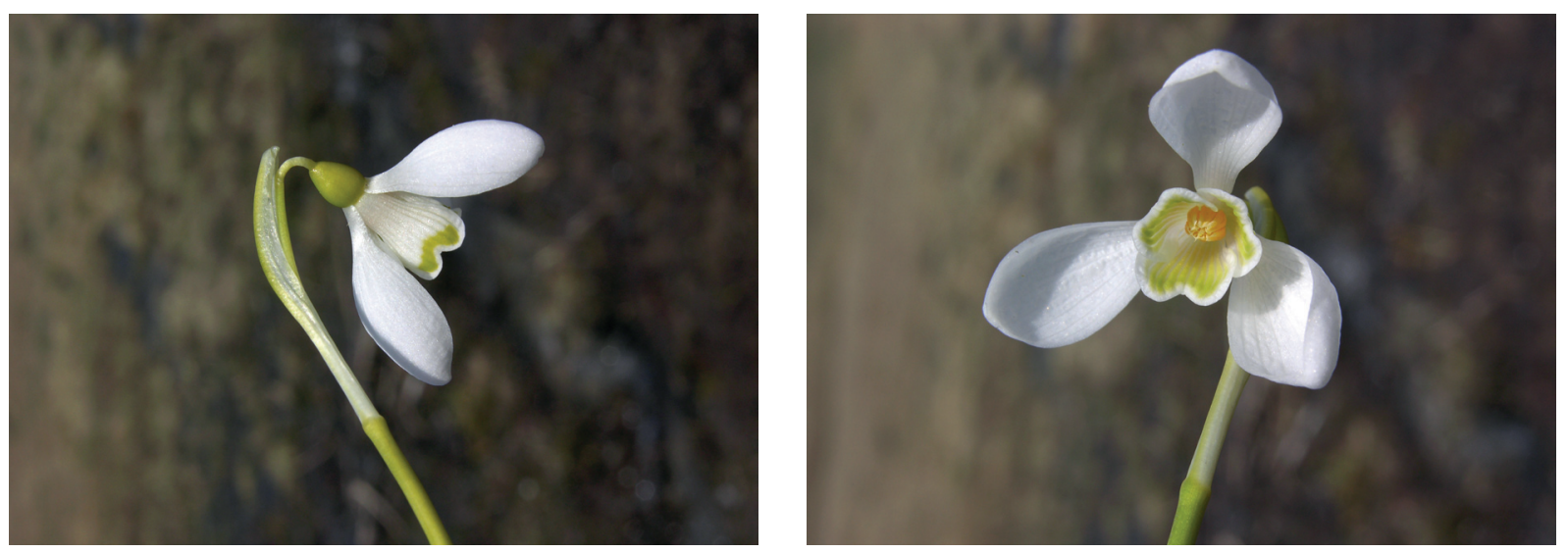

Figure 2 (a, b \& c): Floral appearance and bulb of Galanthus elwesii (photo Z. Hashani)

Slika 2 (a, b \& c): Cvet in gomolj vrste Galanthus elwesii

(foto Z. Hashani).

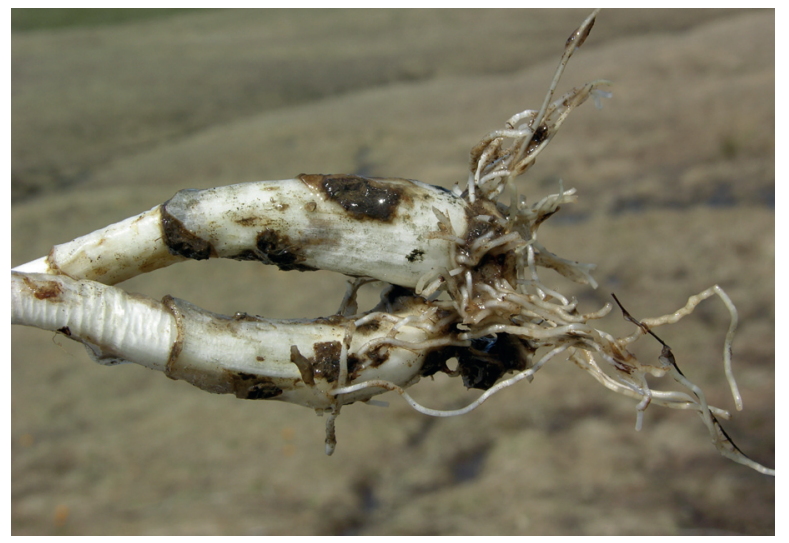


In general, however, G. gracilis is of smaller size, with narrower leaves and smaller flowers than those of $G$. elwesii, so these morphological differences can be established correctly during the first weeks of development, rather than considering only matured specimens.

The species $G$. elwesii blooms in early spring, immediately after snow melt. During the expeditions conducted in 2011-2015, we have come across this rare and important species for the flora of our country which is recorded for the first time in the explored region (coll. Hashani 2011-2015).

Habitat and ecology: In our country, the species grows in subalpine pastures, at an elevation of 1.500 to 1.780 $\mathrm{m}$, often in moist meadows formed by sediments of the Pleistocene epoch/era or earlier, in the growth habitat they are associated with typical species of these environments such as Parnassia palustris and Veratrum sp., along with the threatened species Crocus scardicus.

The species, which was in full flowering phase, was located in the explored areas on 28.04.2012 (in Vraça), on the right side of the road leading to the border with Macedonia (between this road and the Albanian border along Shishtavec), in siliceous substrate (coll. Hashani) (Figure 3).

The population of this species in these areas has a very limited realm, with a small number of individuals (50-100), affected by grazing, landslides, fires, overuse as a decorative and collection plant for export, and other risk factors.

G. elwesii is adapted to grow in mixed substrates with different geological composition of bedrock (Berkov et al. 2008, Hashani et al. 2014, 2015, etc.). Other species encountered in these areas are: Aconitum lamarckii, Aconitum pentheri, Campanula foliosa, Bruckenthalia spiculifolia, Gentianella bulgarica, Pinguicula balcanica, Cerastium cerastioides, Trollius europaeus, Viola tricolor, Carex pauciflora, Geum coccineum, Eriophorum vaginatum etc.

Distribution in Kosovo: In this paper, Galanthus elwesii Hook was first recorded in Kosovo. During the research expedition, dated 28-30.04.2012, on the crossing of transect in the Dragash-Restelica mountain range, at the Vraça-Shishtavec location we encountered the G.elwesii species (coll. Hashani \& Shuka). This species grows mainly in the subalpine pastures up the alpine, wet, hilly meadows of Vraça, extending to the south-west exposure at an altitude of $1,700 \mathrm{~m}$ with a coordinate of $41^{\circ} 55^{\prime} 43^{\prime \prime} \mathrm{N}$; $20^{\circ} 38^{\prime} 58^{\prime \prime} \mathrm{E}$, mainly in silicon substrates.

Seeing the importance of species for the Kosovo flora and the Red Book of Protected Species of Kosovo, we have studied sufficiently herb aceous and fresh material for the $G$. elwesii species. During the expeditions carried out on 10-12. 05. 2014 we also found the species $G$. el- wesii in the same site at altitude $1782 \mathrm{~m}$, in the silicon substrate with coordinates $41^{\circ} 56^{\prime} 50^{\prime \prime} \mathrm{N} ; 20^{\circ} 40^{\prime} 59^{\prime \prime} \mathrm{E}$. (coll. Hashani).

The research and identification of this species were observed, gathering necessary materials such as: photographic data recording (date of legitimization and determination in specific herbal labels), locality altitude, field exposure, slope, geological composition of the terrain, habitat, and also soil samples for chemical analysis in the laboratory.

General distribution: The distribution of $G$. elwesii is relatively wide, beginning from Asia Minor to the Aegean Islands, as well as the mountains of the Balkan Peninsula in the north-west to the Black Sea (Albania, Bulgaria, Greece, Moldova, Romania, Serbia, Turkey and Ukraine) (Barina et al. 2013, 2015, Barina 2017).

Conservation status: This species is included in Appendix II of the Convention on International Trade in Endangered Species of Wild Fauna and Flora (CITES). However, given the narrow area of distribution in Kosovo and the small number of examples found during expeditions, we think this species should be included in the national Red List of vascular plants as a rare and endangered species and should be protected by law. This species is included in several Red Lists in the region, in Serbia with deteriorating status (VU), in Moldova critically endangered (CR), in Bulgaria with endangered status (EN) and deteriorated (VU) in Romania and Ukraine (Davis 2013, Jovanović et al. 2012, 2016, Sennikov \& Phipps 2013).

\section{Conclusions}

Galanthus elwesii is recorded for the first time in the Republic of Kosovo with very limited distribution in subalpine and alpine pastures and for these reasons it is proposed that the species be taken under protection. This species is encountered in habitats with different substrates, mainly siliceous and limestone but it is not obligate to the substrate; it has been adapted to grow in mixed substrate. New species found and identified in the cross-border territory between Kosovo and Albania in the Sharri Mountains (Restelica) indicate the possibility of finding other new species for the flora of Kosovo in that area.

Rrahman Ferizi (D), https://orcid.org/0000-0001-8618-0628 Zeqir Hashani (D), https://orcid.org/0000-0002-7329-8229 Qenan Maxhuni (D), https://orcid.org/0000-0002-2493-6714 Xhavit Mala (D), https://orcid.org/0000-0002-3794-5791 Almir AbdurrahmaniD, https://orcid.org/0000-0002-90031155 

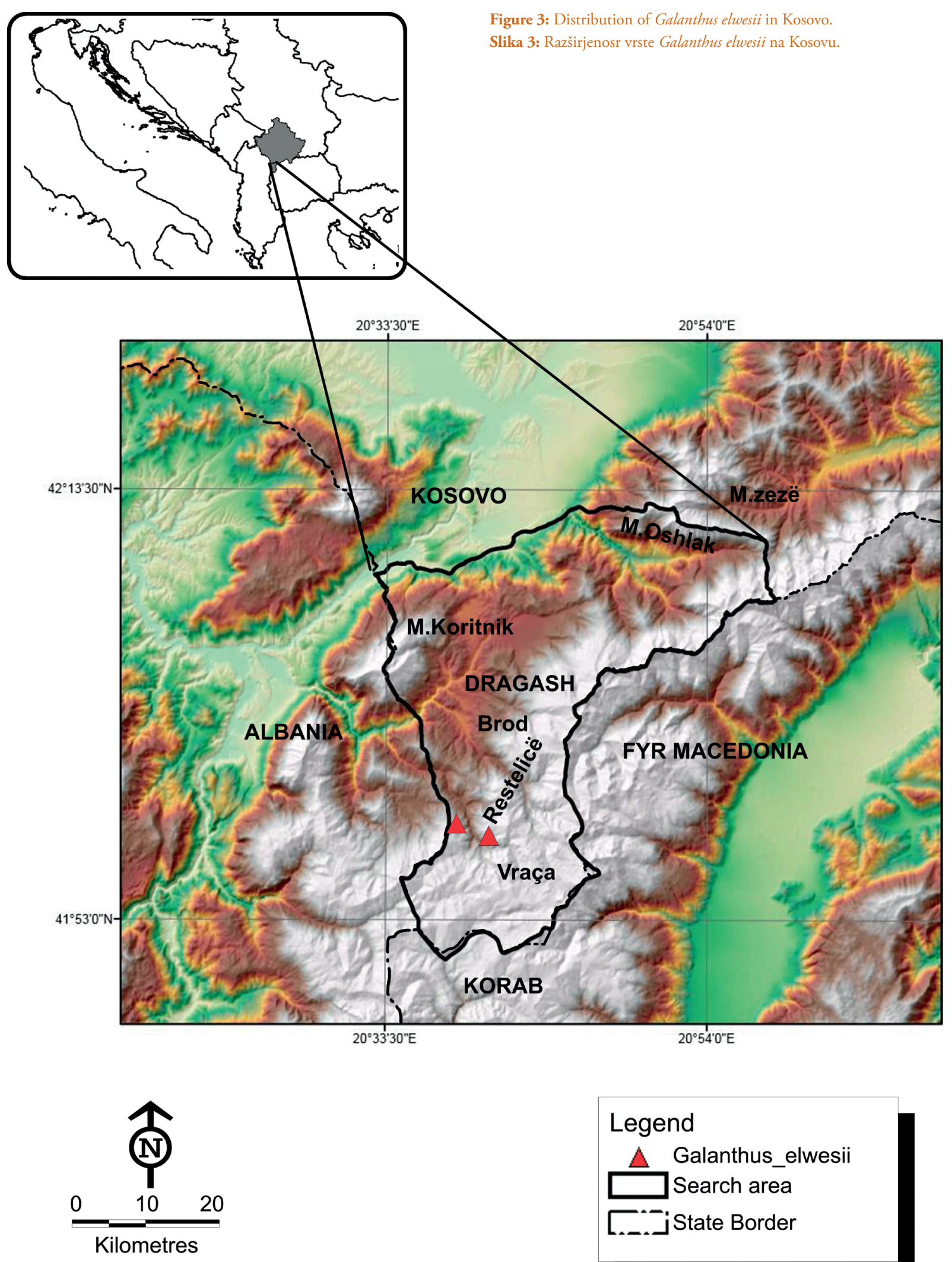

\begin{tabular}{l} 
Legend \\
Galanthus_elwesii \\
Search area \\
\hline... State Border
\end{tabular}




\section{References}

Adamović, L. 1911: Flora of Southeastern Serbia. Yugoslav Academy of Arts and Sciences. 50: 84-140. [in Serbian].

Barina, Z., Rakaj, M. \& Pifkó, D. 2013: Contributions to the flora of Albania, 4. Willdenowia 43(1): 165-184. http//dx.dpi. org/10.3372/wi.43.43119.

Barina, Z., Pifk ó, D. \& Rakaj, M. 2015: Contributions to the flora of Albania, 5. Studia bot. hung. 46(2): 119-140.

Barina, Z. 2017: Distribution atlas of vascular plants in Albania. HNHM, Budapest, 492 p.

Berkov, S., Sidjimova, B., Evstatieva, L. \& Popov, S. 2004: Intraspecific variability in the alkaloid metabolism of Galanthus elwesii. Phytochemistry 65(5): 579-586.

Berkov, S., Bastida, J., Sidjimova, B., Viladomat, F. \& Codina, C. 2008: Phytochemical differentiation of Galanthus nivalis and Galanthus elwesii (Amaryllidaceae). A case study. Biochem Syst Ecol 36(8): 638-645.

Berkov, S., Bastida, J., Sidjimova, B., Viladomat, F. \& Codina, C. 2011: Alkaloid diversity in Galanthus elwesii and Galanthus nivalis. Chem Biodivers 8(1): 115-130.

Bishop, M., Davis A. P. \& Grimshaw J. A. 2006: Snowdrops: Monograph of cultivated Galanthus, 2. ed. The Griffin Press Maidenhead. 9-63.

Davis, A. P. \& Barnett, J. R. 1997: The leaf anatomy of the genus Galanthus L. (Amaryllidaceae). Bot. J. Linn. Soc. 123: 333-352.

Davis, A. P. 1999: The Genus Galanthus L.: A Botanical Magazine Monograph. Timber Press, Portland, Oregon, 334 p.

Davis, A. 2013: The IUCN Red List of Threatened Species Galanthus elwesii.

Didukh Y., P., (ed.). 2009: Red data book of Ukraine. Vegetable kingdom. Global-consulting. Kiev, Ukraine. 900 p.

Dihoru, G., (ed.), Negrean, G. 2009: Cartea rosie a plantelor vasculare din Romania. ISBN-13: 978-9732717059. 630 p.

Duca, R. (ed.)., Chirică, R., Toderaş, I., Teleuță, A., Munteanu, V. \& Dediu, I. 2015: The Red Book of the Republic of Moldova. Chișinău, R. of Moldova. $492 \mathrm{p}$.
Hashani, Z., Maxhuni, Q. \& Shuka, L. 2014: Distribution of plant species of The Koritniku and Brody Mts, based on substrate preference. BSHN (UT) 18: 25-37.

Hashani, Z., Rakaj, M. \& Shuka, L. 2015: New and neglected plant taxa between north-eastern border of Albania and adjacent parts in Kosovo. BSHN (UT) Nr.19: 28-39.

Hooker, J.D. 1875: Galanthus elwesii. Curtis's Botanical Magazine. 31: 61-66

Jovanović, F., Obratov-Petković, D. \& Zlatković, B. 2012: Type Galanthus gracilis Celaka. (Amaryllidaceae) in the flora of Serbia. Faculty of Forestry 106: 101-112.

Jovanović, F., Obratov-Petković, D., Niketić, M. \& Vukojićić, S. 2016: Distribution of the genus Galanthus L. (Amaryllidaceae) in Serbia. Botanica Serbica 40 (1): 69-81.

Peev, D. (ed.)., Vladimirov, V. (co-ed.)., Petrova, A.S., Anchev, M., Temniskova, D., Denchev, C., Ganeva, A. \& Gussev, Ch. 2011: Red Data Book of the Republic of Bulgaria: Volume 1 - Plants \& Fungi. Ministry of Environment and Waters. Sofia, Bulgaria. 887 p.

Rexhepi, F. 1986: Flora of higher mountains of Kosovo. Authority of Textbooks and Teaching in Kosovo, Prishtine, 219 p.

Sennikov A. N. \& Phipps J. B.: Atlas Florae Europaeae notes, 19-22. Nomenclatural changes and taxonomic adjustments in some native and introduced species of Malinae (Rosaceae) in Europe. Willdenowia 43: 33-44.

Shuka, L., Tan, K. \& Malo, S. 2011: New chorological data and floristic notes for Albania. Botanica Serbica 35 (2): 157-162.

Stevanović, V. (ed.), 1999: Red data book of Serbian flora 1. Extinct and critically endangered taxa. Ministry of Environment of the Republic of Serbia, Faculty of Biology, University of Belgrade, Institution for Protection of Nature of the Republic of Serbia, Belgrade, 1-156. [in Serbian]

Stjepanović-Veseličić, L. 1975: Fam. Amaryllidaceae Lindl. In: Josifović, M. (ed.), Flora SR Srbije 7, pp. 596-605, SANU, Beograd.

Strid, A. \& Tan, K. 1991: Mountain flora of Greece. Cambridge University Press. Vol. 2: 975 p.

Tutin, T. G., Heywood, V. H., Burges, N. A., Moore, D. M., Valentine, D. H., Walters, S. M. \& Webb, D. A. 1964-1980: Flora Europaea. Vols. 1-5, Cambridge University Press. 464-452.

Yuzbaşioğlu, S. 2012: Morphological variations of Galanthus elwesii in Turkey and difficulties on identification. Bocconea 24: 335-339. 